\title{
Organizational Justice and Employee Work Passion in Nigerian Universities
}

\author{
Okpu, T. O. ${ }^{*} \quad$ Basuo, B. K. \\ Niger Delta University, Department of Management, Amassoma, Nigeria
}

\begin{abstract}
Organizational Justice is very topical for organizations to achieve competitive edge. Few studies examined the three dimensions of organizational justice and its effect on employee work passion. Using Spearman Rank Order Correlational Coefficient, we tested our hypotheses with a sample of 313 university lecturers. We found that distributive justice had no relationship with employee work passion; procedural and interactional justice had a significant positive relationship with employee work passion.
\end{abstract}

Keywords: Organizational Justice, Distributive Justice, Procedural Justice, Interactional Justice, Work Passion

DOI: $10.7176 /$ EJBM/11-14-06

Publication date:May $31^{\text {st }} 2019$

\subsection{Introduction}

Employee work passion vividly portrays how employees' behave in an organization. Zigarmi, Nimon, Houson, Witt and Diehl, (2009:310) define it as 'an individual's persistent, emotionally positive, meaning-based, state of wellbeing stemming from reoccurring cognitive and affective appraisals of various job and organizational situations that results in consistent, constructive work intentions and behaviors'. It is a more encompassing term than employee engagement because it measures both job and organizational factors that affect employees' cognitive and affective behaviour. Employee work passion connotes strong emotions which leads to positive behaviour at work (Zigarmi, et al, 2009; Gubman, 2004; David, 2012). It describes passionate employees who are concerned about customers' satisfaction, achieving sustainable growth and increasing the profit of the firm (Zigarmi, Nimon, Houson, Witt and Diehl, 2011).

However there is a thin line between work passion and work engagement. Agarwal (2014) argues that work engagement involves employees investing their cognitive, emotional and physical energy in the work place, which provides a more comprehensive explanation for job performance. This falls within the definition of work passion as propounded by Zigarmi et al (2009).

Employee Passion is important in creating Customer Devotion and Organizational Vitality (Zigarmi, et al 2009). David (2012) believes it is necessary to study work passion because it has great potential for generating positive changes in employees and organizations.

In response to the benefits associated in having employees with work passion, studies have been carried out with other constructs to determine its effectiveness in organizations such as: Leadership behaviour and values (Egan, Turner and Blackman, 2017); human resources policies and practices (David, 2012); organizational and job factors (Zigarmi et al, 2009); individual and organizational creativity (Liu, Chen and Yao, 2011); job satisfaction, turnover intentions, job performance organizational citizenship behaviour (Burke, Astakhova and Hang, 2015); work cognition inventory (Kim, Nimon, Song and Zigarmi, 2014; Astakhova, 2014); Work Performance (Ho, et al 2011); Culture (Burke and Astakhova, 2015); Pro-organizational behaviour (Kong, 2015).

These researches notwithstanding, problems still abound in harnessing the passion of workers in organizations. Work passion survey in China revealed that only $2.5 \%$ of respondents had work passion (Chen, 2010). Hagel et al (2014) reports that $88 \%$ of US workforce do not have passion for their job.

To fill the gap in literature, we proposed that organizational justice will positively influence employees' work passion. There is paucity of research in this area. Previous studies from the West and Eastern countries examined organizational justice and employee engagement (Alvi and Abbasi, 2012; Hassan and Jubari, 2010). We moved beyond engagement to investigate work passion because according to Zigarmi et al (2009) both organizational and job factors influences employees' work passion while only job or organizational commitment affects employee engagement. Gubman (2004) describe engagement as an attraction for your working environment while passion is an intense love for what you do and how you do it. Zigarmi et al (2011) also examined procedural and distributive justice in their work. We departed from this view by examining the three dimensions of organizational justice procedural, distributive and interactional Justice on work passion. Greenberg in Byrne and Cropanzano (2001) called for further research on organizational justice as a whole and not just the parts. He believe there is need to integrate distributive, procedural, and interactional justice in a study. Furthermore our study is carried out in Nigeria, which is a different setting from previous scholarly works.

This study is an investigation of the effect of organizational justice on employees' work passion in Nigerian Universities. The following operational framework is drawn to give focus to our work. 


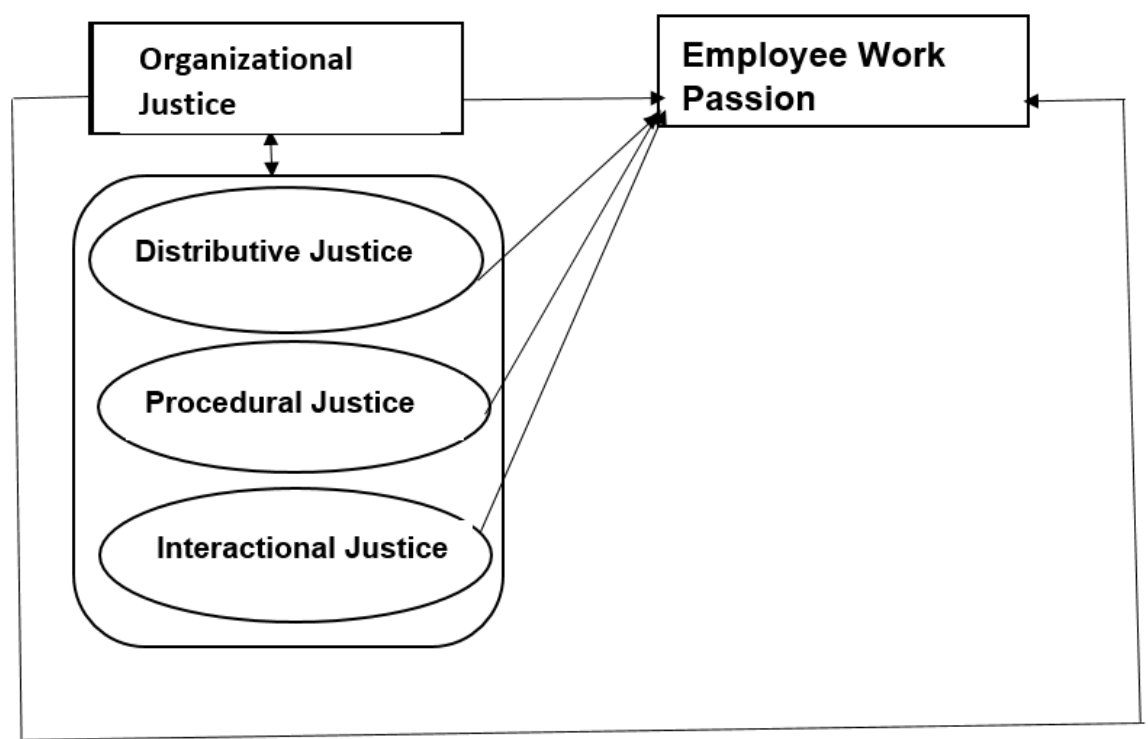

Fig.1 Operational Framework

\subsection{LITERATURE REVIEW}

The review of literature discussed Organizational Justice and its empirical referents. This was followed by employee work passion and the association between organizational justice and employee work passion.

\subsection{Organizational Justice}

From time immemorial people have been concerned about how they are treated - fairly or unfairly. Justice describes individual's perception of right or wrong treatment in a community context. The idea of justice is rooted in human nature with the inherent belief that people should be treated equitably (Lather and Kaur, 2015). Early philosophers like Aristotle believe that there should be Justice in the allocation of resources among people (Ross, 1925). This is in line with the Equity theory propounded by Adams (1965). Employees examine the ratio of their inputs (time, effort, cognitive resources) to their outcomes (pay, promotion, opportunity for growth) and compares this to a referent other. If employees perceive that their input/outcome is unfair, they could reduce their effort, have negative feelings towards the organization, be demotivated (Cropanzano, Byrne, Bobocei and Rupp, 2001; Shkoler and Tziner, 2017).

The rise to prominence of organizational justice in the management literature was as a result of the collective efforts of five researchers - Robert Bies, Robert Folger, Jerald Greenberg, Allan Lind and Tom Tyler - (Byrne and Cropanzano, 2001). The concept organizational justice was introduced by Greenberg (1987). He sees organizational justice as being concerned with fairness issues in organizations and is useful in explaining a wide variety of organizational behaviour.

According to Cropanzano (2007) organizational justice is the binding force that makes employees' work together cohesively. It is defined as "a personal evaluation about the ethical and moral standing of managerial conduct" (Cropanzano 2007:35). Organizational justice deals with individual's perception of fairness in decisions taken (distributive justice), the processes that are used in arriving at decisions (procedural fairness) and the interpersonal and informational treatment received (interactional Justice) (Colquitt, 2001).

The concept of organizational justice has found strong support in enhancing other work related outcomes. In their study Moghimi, Kazemi and Samiie (2013) reports organizational justice -distributive, procedural and interactional justice - positively influences employee quality of work life. Deschamps et al (2016) showed how transformational leadership is positively associated with distributive, procedural, and interactional justice leading to high motivation of employees.

Researchers have argued about the right measures of organizational justice. Early works looked at it from two dimensions namely: distributive and procedural justice (Greenberg, 1987). This gave rise to the debate of three or four dimensions (Kovacevic, Zunic and Mihailovic, 2013; Colquitt 2001; Cropanzano 1997). However we used the three dimensions measurement of distributive, procedural and interactional justice in line with several studies (Krishnan, Loon, Ahmad, Binti and Yunus, 2018; Deschamps, Rinfret and Legace 2016;Tatum \& Eberlin, 2006; McDowall \& Fletcher, 2004; Cropanzano et al 2001).

\subsubsection{Distributive Justice}

Distributive justice deals with allocations of outcomes to employees. How fair are these outcomes that employees 
receive? (Cropanzano, Bowen and Gilliland, 2007).

Equity theory is at the heart of distributive justice. Adams (1963) theory of equity looked at the ratio of the input and output of workers in relation to others. Workers compare their rewards to their perceived work contributions in relation to the rewards/contributions of colleagues. Employees are motivated when they feel that there is equity in the distribution of organizational resources; and have feelings of distress or are demotivated when they perceive inequity in the distribution of organizational resources as compared to what others have.

Research has shown that workers reduce their performance when they feel they are underpaid and increase their performance when they believe they are overpaid (Adams and Freedman, 1976; Greenberg, 1982). Malmir, Esfahani and Emami (2013) revealed in their study that employees are dissatisfied with their benefits and hence believe that there is no distributive justice in their firm. Altaf et al (2011) found strong relationship between distributive justice and employee behaviour. Employees were more loyal, satisfied, and performed better because they were happy with their compensation and benefits in the Pakistani hospital. This improved the performance of the organization. In a similar vein, Olafsen et al (2015) report that employees who receive more money experience greater distributive justice.

Cropanzano et al (2007) believe it is in management's best interest to treat employees equally, rewarding them according to their contributions and needs. According to them this can be done by providing a hybrid approach to equity and equality in organizational processes.

After the initial hype about distributive justice, questions began to arise on how organizations administer their pay plans and what process they use in grievance procedures. There was a shift to the perceived fairness of how decisions were being made from the fairness about decisions already made. This gave rise to the prominence of procedural justice (Greenberg, 1990).

\subsubsection{Procedural Justice}

According to Greenberg (1990:402) procedural justice is 'the perceived fairness of the policies and procedures used to make decisions'. Procedural justice describes how outcomes are distributed equitably. It ensures a fair process, free of bias, accurate and representing all important stakeholders while complying with ethical norms (Cropanzano et al, 2007).

Thibaut and Walker (1975) propounded the concept of procedural justice in their investigation of equity settlement of legal disputes where they introduced the concept of process control and decision control. Colak and Erdost (2004) reiterate that workers would settle for some control over decision making (process control) when they cannot have full control (decision control) over the process of making decisions. Employees perceive organizational policies as being fair when they are involved in the decision making process. This involves giving employees voice in an organization. Research has shown that when employees are involved in the decision making process, they are more committed, engaged and passionate about their work (Okpu and Kpakol, 2018; Okpu, 2016).

Cropanzano et al (2007) believe procedural justice is important in organizations as it affects workers' perception of the whole organization. If workers perceive the organizational process as being fair and just, they display greater loyalty, commitment and organizational citizenship behaviour. This supports Altaf et al (2011) findings that procedural justice leads to greater loyalty and organizational performance. Olafsen et al (2015) found strong support for procedural justice, need satisfaction and intrinsic work motivation. They report that perceived fairness in the procedure used in compensation gave employees the feeling they had more autonomy and control in their work. In contrast, research by Krehbiel and Cropanzano (2000) revealed that workers display feelings of anger and frustration when they perceive they were given an unfavourable outcome by an unfavourable process; they also portrayed feelings of guilt and anxiety when they were given a favourable outcome by an unfavourable process.

\subsubsection{Interactional Justice}

Bies (2001:2) introduced the concept of interactional justice arguing for a more holistic measurement of organizational justice variables that encapsulates the 'human and existential dimensions' that are not emphasized and appreciated in the theory of organizational justice. Interactional justice deals with how employees are treated by management; does management respect employees and provide them with accurate information, taking into cognizance individual differences (Hassan and Jubari, 2010).

Cropanzano et al (2007) asserts that Interactional justices is made up of interpersonal justice (fair treatment by superiors) and informational justice (relevant and timely information given to employees). Interpersonal justice and informational justice are sometimes studied separately hence the four dimensions of organizational justice propounded by some scholars (Colquit, 2001). Bies and Moag (1986) believe that justification, truthfulness, respect and propriety are necessary criteria for interactional justice.

The three justice dimensions are very important in organizational processes. The plethora of researches has buttressed this fact. Management practitioners are beset with how to inculcate these positive benefits of organizational justice to build on their distinctive capabilities. Work passion offers a way forward in ensuring that workers trust and believe in the fairness of management and this can lead to positive outcomes to their work. 


\subsection{Employee Work Passion}

Passion is "a strong inclination toward an activity that people like, find important, and in which they invest time and energy" (Vallerand, 2008:1). Vallerand distinguished between two types of passion: harmonious passion (freedom to engage in activities people love) and obsessive passion (an uncontrollable urge to engage in certain activities). He believes obsessive passion controls an individual and has negative consequences such as conflicts and frustrations because of the individual's addiction to that activity. In harmonious passion individuals freely engage in the activity and are not addicted to it. There is no conflict between the activity and other facets of the individual's life.

Harmonious passion has been used to describe employees' work passion in organizations (Zigarmi et al 2009; Ho, Wong and Lee, 2011; Astakhova, 2015). Zigarmi et al (2011) differentiated work passion from engagement with the argument that engagement is more connected with organizational commitment and too weak to describe the affective, cognitive and behavioural aspects of work passion, which gives employees a strong sense of work identify and satisfaction. They believe employees with work passion are more likely to have a sense of job wellbeing yielding positive outcomes to organizational processes. In a similar vein, Ho, Wong and Lee (2011) believe individuals with work passion have a deep liking and enjoyment for their work; they see the work as being very important and strongly identify with what they do. Birkeman and Buch (2015) in support describes such employees as seeing their job as part of their social identity which provides intrinsic satisfaction and extrinsic gratification. To them engagement is not stable, but fluctuates over time depending on employees' state of mind, energy and experience; while passion is stable and does not fluctuate, rather it describes employees relationship with their work, how they identify with their jobs while present or absent in the organization. In essence they see passion as being a part of the employee whether present at work or not.

This distinction between passion and engagement can be traced to self-determination theory.

Deci and Ryan (2000) self-determination theory is concerned with the basic psychological needs of autonomy, competence and relatedness and how they affect individuals' well-being, growth and motivation. This theory is at the heart of employee work passion because it explains the intrinsic satisfaction employees derive from having autonomy in carrying out their work and the satisfaction they derive from the strong sense of self-identity with work (Birkeland and Buch, 2015). Zigarmi et al (2009) identified the following factors as necessary for employees to maximize their work passion - Meaningful Work, Autonomy, Collaboration, Fairness, Recognition, Career Growth, Connectedness to Colleagues, and Connectedness to Leader.

Nimon, Zigarmi, Houson, Wit and Diehl (2011) posit that feedback describes employees' perception of organizations providing them with accurate and timely information about their job performance; Meaningful work has to do with individual's perception of the importance of their work inside and outside the organization; collaboration is the extent to which people share information and ideas in the organization as against competition; connectedness to leader describe a situation of a strong and open relationship existing between employees' and their supervisors characterized by information sharing, building rapport and manager's acting in the best interest of employees; connectedness to colleagues is characterized by collaboration, information sharing and trust among colleagues; growth deals with opportunities employees have to reach the peak of their career by the provision of clear career path and criteria for growth opportunities; while fairness describes how equitably and justly organizational outcomes and processes are distributed to employees.

Studies have shown strong support for the importance of autonomy, meaningful work, and social relationships in building work passion and the positive organizational outcomes it supports such as: psychological wellbeing and increased employee performance (McAllister et al, 2017; Thibault-Landry et al 2018); positive job attitudes (Kim et al, 2015); feelings of happiness in the completion of their task as opposed to engaged employees (Baard, Deci and Ryan, 2004; David 2012). Workers also display behaviours such organizational citizenship behaviour, use of discretionary effort, lower employee turnover and higher performance (Astakhova, 2015; Burke, Astakhova and Hang, 2015; Zigarmi and Nimon, 2011; Ho, Wong and Lee, 2011).

Self-determination theory explains that when employees' psychological needs of competence, autonomy and relatedness are being met, it builds their self-concept, making them deliberately engage in work activities passionately; and this passion is self-determined (Landry et al 2018). Research (Landry, et al 2018) has shown the positive association between self-determination theory and employee work passion. Empirical evidence suggests that job autonomy, task variety, meaningful work and performance expectations are positively related to employees' work behaviour leading to work passion.

\subsection{Organizational Justice and Employee Work Passion}

Zigarmi and Nimon (2011) demonstrated that procedural fairness and distributive fairness among other factors are very important in building employees' work passion. Zigarmi et al (2009) asserts that organizational processes and procedures that are equitable and applied indiscriminately to all employees in a fair and consistent manner will help in developing work passion in employees, improving organizational performance in terms of sustainable growth and increased profit. Zigarmi et al (2011b) stated that to improve employee work passion management 
should design the work environment to ensure that importance is given to employees' involvement in the decision making process (procedural justice).

Luo et al (2014) found that poor compensation packages among other factors led to Chinese health employees exhibiting low work passion. Fariba et al (2013) found a direct and significant relationship between organizational justice dimensions - procedural, distributive and interactional - and employee commitment. He et al (2013) reported a strong relationship between procedural justice and employee engagement.

While there is paucity of research on the effect of organizational justice on employee work passion, studies (Upasna, 2014; Alvi and Abbasi, 2012; Hassan and Jubari, 2010) have demonstrated strong correlations between organizational justice and employee engagement. Going by the arguments that passion is a stronger form of engagement, we hypothesized that these positive relationship between employee engagement and organizational justice may also hold true for organizational justice and employee work passion. Zigarmi et al (2011b:212) also used the term engagement and passion loosely when they reported in the practical implication of their study that "practitioners should be mindful of the content of surveys designed to assess employee work passion or engagement." With the foregoing, the following hypotheses were stated to verify our contentions:

$\boldsymbol{H}_{0} 1$ there is no significant relationship between distributive justice and employee work passion.

$\boldsymbol{H}_{0} 2$ there is no significant relationship between procedural justice and employee work passion.

$\boldsymbol{H}_{0} 3$ there is no significant relationship between interactional justice and employee work passion.

\subsection{Method}

The study adopted the correlational survey research design. The structured questionnaire was used for the collection of data from respondents. The population of the study comprised all academic staff in the three universities in Bayelsa State which was 1654. Using Krejcie and Morgan (1970) table on Sample size determination, a corresponding sample size of 313 was obtained. The scale used in measuring Organizational Justice was adapted from the work of Colquitt (2001), for Employee Work Passion, we adapted Nimon et al (2011) Work Cognition Inventory (WCI) Questionnaire and Nimon and Zigarmi (2015) revised WCI questionnaire. The questionnaire adapted the 4-point Likert type of scale, with response category ranging from 4 (strongly agree) to 1(strongly disagree). The questionnaire had two sections: Section A comprised demographic information such as years of experience, gender, age, qualification and rank. While section B had 44 questions eliciting respondents view on organizational justice and employee work passion. However out of the 313 copies of questionnaire distributed, only 287 were usable, representing approximately $92 \%$ response rate.

Our variables had construct validity since they had been pretested in previous studies (Nimon et al, 2011; Kim et al, 2015; Zigarmi and Nimon, 2015; Thibault-Landry et al, 2018). The Cronbach Alpha was used to test for reliability.

According to Bryman and Bell (2003) alpha coefficient of 0.70 and above is regarded as efficient, hence our variables were reliable as given by the table below.

Table 1: reliability analysis scale (Alpha)

\begin{tabular}{|l|l|l|l|}
\hline Variable & Number of cases & Number of items & Alpha \\
\hline Organizational Justice & & & \\
1. Distributive & 287 & 4 & 0.731 \\
2. Procedural & 287 & 7 & 0.765 \\
3. interactional & 287 & 9 & 0.843 \\
\hline Employee work passion & 287 & 24 & 0.731 \\
\hline
\end{tabular}

\section{Source: research data}

With the use of Statistical Package for Social Scientists, the hypotheses were tested with Spearman Rank Order Correlation to establish the association between organizational justice and employee work passion. Our confidence interval was set at 0.05 level of significance. 


\subsection{Data Results}

\subsection{Demographic Analysis}

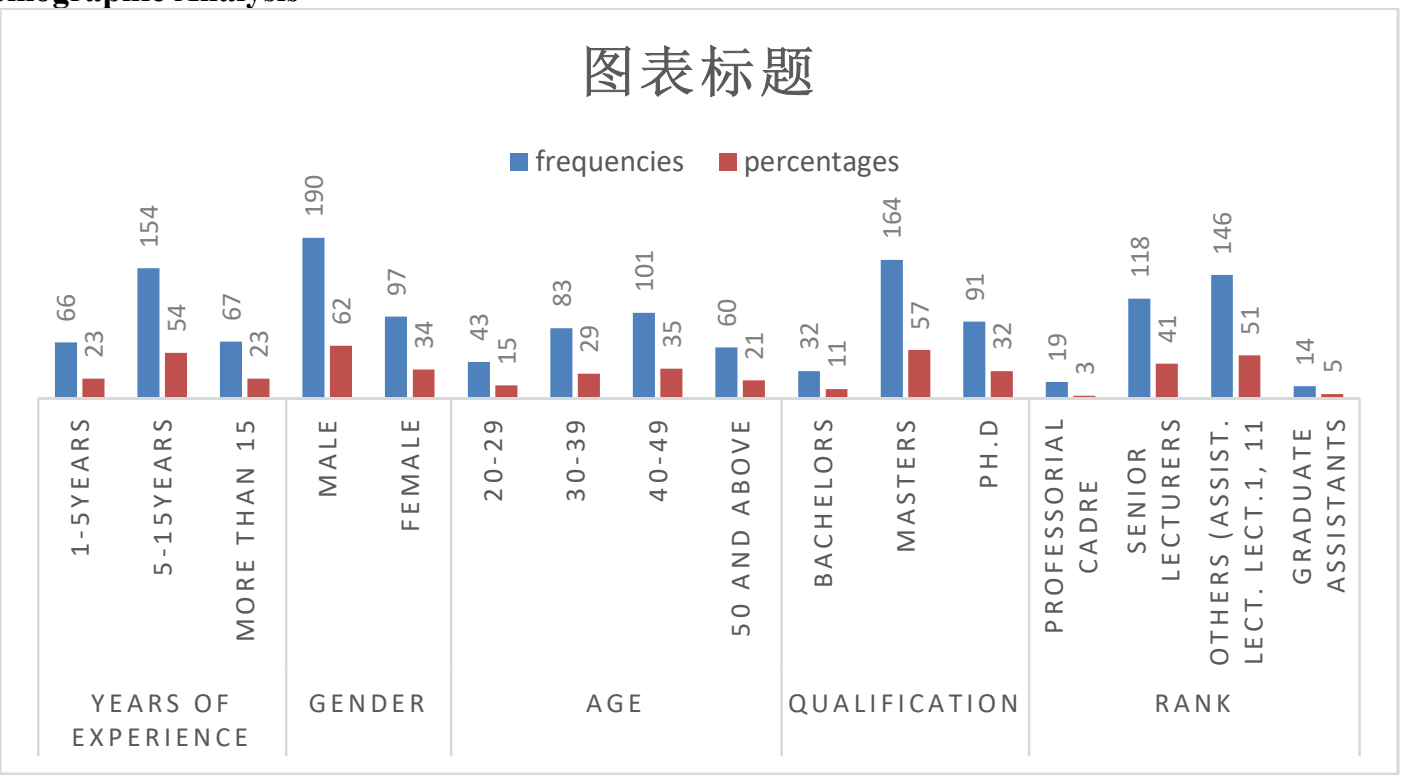

Figure 2: Demographic data

The demographic analysis revealed that a higher proportion of the participants were male (62\%). Most people had worked in the university above five years (54\%) and the maximum age range is $40-49$ years representing $35 \%$ of the respondents. Academic staff with Master's degree were more (57\%), followed by those with $\mathrm{Ph} . \mathrm{D}(32 \%)$ and Bachelor's (32\%). There are more assistant lecturers, lecturer 1 and lecturer 11 in the universities $(51 \%)$, closely followed by senior leturers (41\%). Professors were $19 \%$ and graduate assistants $14 \%$.

\subsection{Univariate Analysis}

Our research instrument utilized the 4-point Likert type of Scale with response category $\mathrm{SA}=4, \mathrm{~A}=3, \mathrm{DA}=2$, $\mathrm{SDA}=1$. The base mean for the scale is 2.00 .

Table 2: Descriptive Statistics of Organizational Justice

\begin{tabular}{|l|r|r|r|r|r|r|r|}
\hline & \multicolumn{1}{|c|}{$\mathrm{N}$} & \multicolumn{1}{c|}{ Mean } & Std. Deviation & \multicolumn{2}{|c|}{ Skewness } & \multicolumn{2}{|c|}{ Kurtosis } \\
\cline { 2 - 8 } & Statistic & Statistic & Statistic & Statistic & Std. Error & Statistic & Std. Error \\
\hline distributive & 287 & 2.6446 & .71754 & -.253 & .144 & -.656 & .287 \\
procedural & 287 & 2.4918 & .57298 & .538 & .144 & .109 & .287 \\
interactional & 287 & 2.6010 & .66170 & -.161 & .144 & -.344 & .287 \\
Valid N (listwise) & 287 & & & & & & \\
\hline
\end{tabular}

Table 2 is a summary of the frequency distribution of respondents' views of organizational justice in Nigerian Universities. The mean value for distributive, procedural and interactional justice is high (i.e from 2.49 and above). This indicates that participants believe that the outcomes they receive for their efforts is justified and equitable in comparison to referent others in the industry. The procedure used in arriving at these outcomes is fair and free of bias. They were also of the view that they are respected by their supervisors who communicates information to them in a timely and accurate manner. Workers in Nigerian universities believe there exist distributive, procedural and interactional justice in the school system.

Table3: Descriptive Statistics of work Passion

\begin{tabular}{|l|r|r|r|r|r|r|r|}
\hline & \multicolumn{1}{|c|}{$\mathrm{N}$} & \multicolumn{1}{c|}{ Mean } & \multicolumn{1}{c|}{ Std. Deviation } & \multicolumn{2}{c|}{ Skewness } & \multicolumn{2}{c|}{ Kurtosis } \\
\cline { 2 - 8 } & Statistic & Statistic & Statistic & Statistic & Std. Error & Statistic & Std. Error \\
\hline autonomy & 287 & 3.1382 & .68098 & -1.147 & .144 & 1.416 & .287 \\
collaboration & 287 & 2.9628 & .71677 & -1.030 & .144 & .650 & .287 \\
concolleague & 287 & 2.7340 & .76852 & -.338 & .144 & -.736 & .287 \\
conleader & 287 & 2.7468 & .77710 & -.328 & .144 & -.740 & .287 \\
fairness & 287 & 2.9280 & .84654 & -.843 & .144 & -.283 & .287 \\
feedback & 287 & 2.9930 & .81408 & -.910 & .144 & .056 & .287 \\
growth & 287 & 2.7619 & .78806 & -.617 & .144 & -.050 & .287 \\
meaningfulwork & 287 & 2.9024 & .75040 & -.846 & .144 & .597 & .287 \\
Valid N (listwise) & 287 & & & & & & \\
\hline
\end{tabular}


Table 3 is a summary of the frequency distribution of respondents' views of employees' work passion in Nigerian Universities. The mean value for the eight dimensions of employee work passion is high (i.e., from 2.73 and above). This indicates that workers' believe they have freedom in performing their task without interference. There is collaboration among colleagues. Their co-workers are helpful and positive with a professional and personal interest being displayed at all times. They believe their bosses act in their best interest and the compensation they receive is proportionate to the effort they expend. Constructive feedback obtained from their managers enables them to make improvements in their job. They can chart their future career path in the university as there is opportunity for growth and personal development. The respondents see their work as being very meaningful because it enables the organization to achieve its purpose. From the univariate analysis, workers are very passionate about their work in Nigerian universities.

\subsection{Bivariate Analysis}

Table 4: Correlation matrix for distributive justice and work passion

\begin{tabular}{|lll|r|r|}
\hline & & distributive & \multicolumn{1}{c|}{ work passion } \\
\hline & \multirow{3}{*}{ distributive } & Correlation Coefficient & 1.000 & .116 \\
& & Sig. (2-tailed) &. & .050 \\
& & $\mathrm{~N}$ & 287 & 287 \\
& & Correlation Coefficient & .116 & .050 \\
& \multirow{2}{*}{ work passion } & Sig. (2-tailed) & 287 & 1.000 \\
& & $\mathrm{~N}$ &. \\
& & & 287 \\
\hline
\end{tabular}

The result of the Spearman Rank Correlation Coefficient for the relationship between distributive justice and employee work passion is presented in table 4 above. For hypothesis one the coefficient $r=0.116$ and $p=.050$. This shows a weak relationship, therefore the first null hypothesis is accepted: there is no significant relationship between Distributive Justice and Employees' Work Passion.

Table 5: Correlation matrix for procedural justice and work passion

\begin{tabular}{|lll|r|r|}
\hline & & procedural & work passion \\
\hline & \multirow{3}{*}{ procedural } & Correlation Coefficient & 1.000 & $.198^{* *}$ \\
& & Sig. (2-tailed) &. & .001 \\
& & $\mathrm{~N}$ & 287 & 287 \\
& & Correlation Coefficient & $.198^{* *}$ & .001 \\
& \multirow{3}{*}{ workparman's rho } & Sig. (2-tailed) & 287 & 1.000 \\
& & $\mathrm{~N}$ &. \\
& & & 287 \\
\hline
\end{tabular}

**. Correlation is significant at the 0.01 level (2-tailed).

The result of the Spearman Rank Correlation Coefficient for the relationship between procedural justice and employee work passion is presented in table 5 above. For hypothesis two the coefficient $\mathrm{r}=0.198$ and $\mathrm{p}=0.001$. Therefore the second null hypothesis is rejected: there is a significant positive relationship between Procedural Justice and Employees' Work Passion.

Table 6: Correlation matrix for interactional justice and work passion

\begin{tabular}{|lll|r|r|}
\hline & & interactional & work passion \\
\hline & \multirow{4}{*}{ Spearman's rho } & Correlation Coefficient & 1.000 & $.191^{* *}$ \\
& & Sig. (2-tailed) &. & .001 \\
& & $\mathrm{~N}$ & 287 & 287 \\
& \multirow{2}{*}{ work passion } & Correlation Coefficient & $.191^{* *}$ & .001 \\
& & Sig. (2-tailed) & 287 & 1.000 \\
& & $\mathrm{~N}$ &. \\
\hline
\end{tabular}

**. Correlation is significant at the 0.01 level (2-tailed).

The result of the Spearman Rank Correlation Coefficient for the relationship between interactional justice and employee work passion is presented in table 6 above. For hypothesis three the coefficient $r=0.191$ and $p=$ 0.001. Therefore the third null hypothesis is rejected: there is a significant positive relationship between interactional Justice and Employees' Work Passion.

From the results above, we found that:

1. There is no significant relationship between distributive justice and employee's work passion.

2. There is a significant positive relationship between procedural justice and employee's work passion.

3. There is a significant positive relationship between interactional justice and employee's work passion. 


\subsection{Discussions}

The importance of having employees who are highly passionate about their work and organization is very important to management. It is believed this will drive the organization to have a competitive edge in the industry (Zigarmi et al 2009; Baard et al, 2004). This has led to the investigation of job and organizational characteristics that could be a positive driver for employee work passion.

Following this line of argument, this study investigated the effect of organizational justice on employee work passion. Drawing from Self-determination Theory Deci and Ryan (2000), employees exhibited intrinsic satisfaction from having autonomy in their job and a strong sense of identification with the organization.

We found from our studies that distributive justice had no significant relationship with employee work passion. This is not surprising because the teaching profession in Nigeria is one of the least recognized in the country. There has been countless industrial actions by the country's Academic Staff Union of Universities (ASUU) over poor funding of Nigerian Universities and poor remuneration given to lecturers across the nation. Research done by mysalaryscale.com (2017) showed that the educational sector in Nigeria did not make the top 50 companies with the highest salaries. Rather education and teaching profession were among the least 10 professions in Nigeria with the least salaries. The low remuneration package offered to university lecturers in Nigeria, led participants to report that their salary and promotions are not commensurate with the effort they put in their job, rather they are underpaid. This implies distributive justice does not influence their work passion. Olafsen et al (2015) also report that distributive justice had no relationship with need satisfaction or autonomy. This is similar to Luo et al (2014) contention of low work passion in Chinese health workers as a result of poor compensation package as well as others factors.

In contrast to our findings, Altaf et al, (2011) in their research of Pakistani Hospital observed that workers were more loyal, satisfied, and with more enhanced performance as a result of distributive justice fairness in the organization. These buttresses Cropanzano et al (2007) advice that it is in management's best interest to reward employees according to their contributions and needs, because distributive justice is very important in building workers' work passion (Zigarmi and Nimon, 2011).

We found in our study that procedural justice had a strong positive relationship with employee work passion. The procedures used in the university to arrive at pay and promotions outcomes are seen as fair and free of bias. Employees believe these procedures are based on accurate information and they have the liberty of appealing if they see the decisions as being unfair. However few studies directly measured the association of procedural justice to work passion. Our findings is similar to Olafsen et al (2015) study which found procedural justice to be strongly associated with employees' need satisfaction and autonomy (an aspect of work passion). In their structural model, employees' who had supportive work environment (collaboration, connectedness to colleague and leader) displayed higher need satisfaction and autonomy. Studies have also shown that procedural justice has a strong significant relationship with employee commitment to the organization (He et al, 2013; Upasna, 2014; Alvi and Abbasi, 2012; Hassan and Jubari, 2010).

Interactional justice was positively related to employee work passion. Employees believe their supervisors are polite and treats them with dignity and respect. There is a good chain of communication and decision making procedures. This finding is similar to Hassan and Jubari (2010) research of the existence of a positive relationship between interactional justice and employees' loyalty and commitment to the organization. When employees are treated with dignity and respect, it fosters a positive relationship between them and their superiors improving the quality of their working experience. In a similar vein, Agarwal (2014) also found strong support for interactional justice positively affecting employees' sense of work identification and satisfaction.

\subsection{Conclusion and Implications}

This study has contributed immensely to the literature on organizational justice and work passion. It is among the few studies that have empirically ascertained the relationship of the different dimensions of organizational justice to work passion. Distributive justice had no significant relationship with employee work passion. Procedural and Interactional Justice increases employee work passion in Nigerian Universities.

Theoretically, this study has added to the literature on organizational justice dimensions on employee work passion. It showed a direct positive association between procedural and interactional justice on employee work passion. Employees believed the procedures used in arriving at pay and promotions are equitable because the process is fair and they are able to express their views regarding the decisions arrived at. Employees are also emotionally, cognitively and affectively committed to the organization by the presence of interactional justice because they have good working relationship with their colleagues and superiors. Supervisors respect and provides timely information to them.

This study confirms the findings of other studies (Fariba et al 2013; He, et al, 2013; Zigarmi et al 2011b). In Nigerian Universities procedural and distributive justice increases employees' work passion. There is autonomy, collaboration, growth, feedback with employees seeing their work as being meaningful to the society at large. It also lends support to Luo et al (2014) research that distributive justice does not affect employees' work passion. 
Fig.2 a model of organizational justice and employee work passion

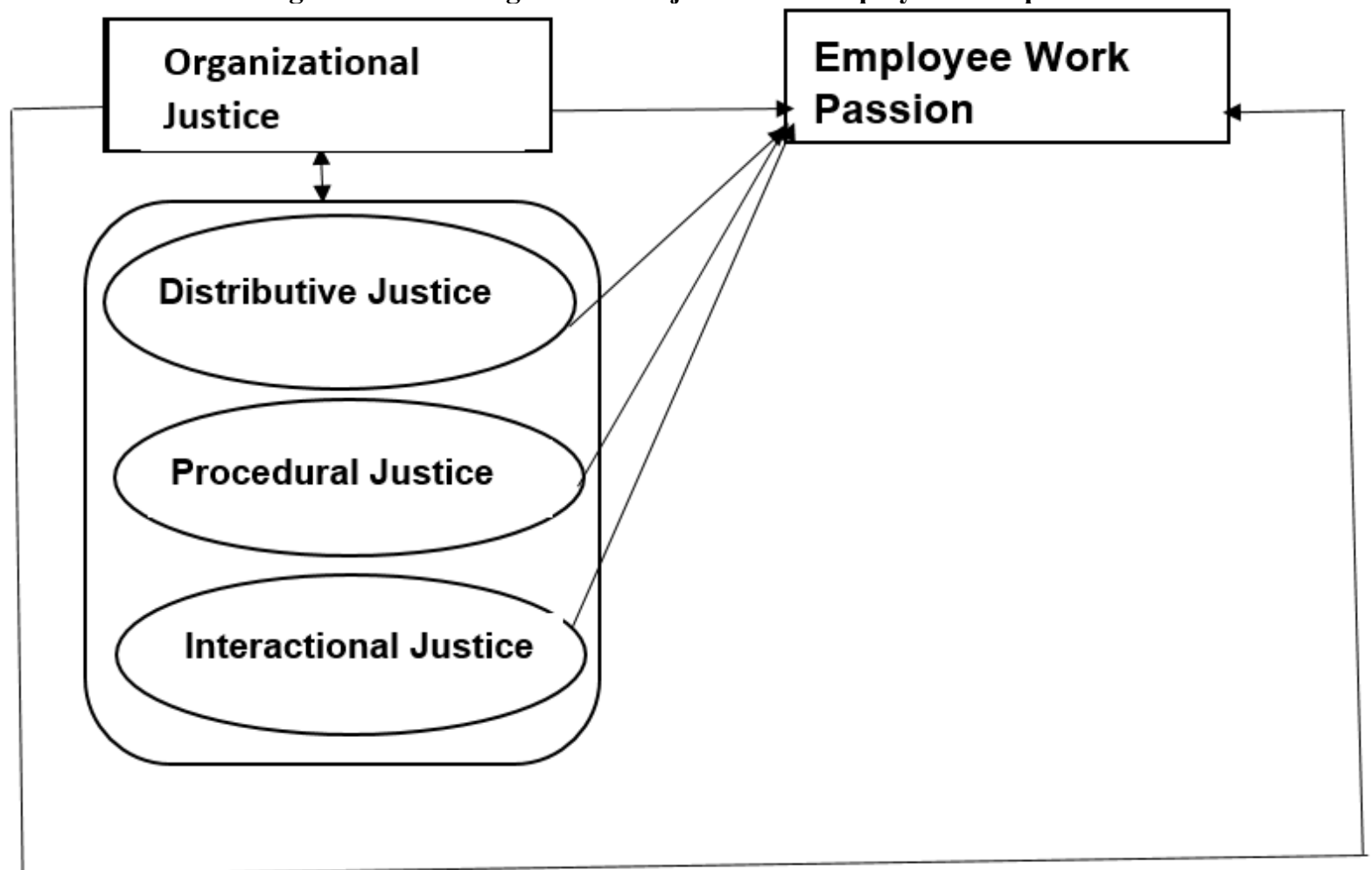

Note: broken arrows indicate non-significant association; straight arrows indicate significant associations

Management practitioners should be cognizant of the fact that procedural and interactional justice will affect employees' work passion. Therefore when employees' have voice in the process used in arriving at decisions in the organization it will improve their work passion. When supervisors treat employees with respect, provide timely information with open communicational process, workers will be more loyal, willing to go the extra mile for the organization and totally dedicated to their work. Procedural and interactional justice makes employees see believe they have autonomy, collaboration, growth, feedback and meaningful work.

\subsection{Limitations and future research}

The geographical scope for this work was based on just one state out of the 36 states in Nigeria, hence the findings of the study cannot be generalized across Nigerian Universities. The study was a nomothetic study with the use of quantitative data. Using triangulation of methodology would provide richer insight on the proposed relationship between Work Passion and Organizational Justice. Future research could consider this perspective. There is also need to look at other industries in the country to see the association between organizational justice and work passion.

\section{Reference}

Adams, J. S. (1963) toward an understanding of inequity. Journal of Abnormal Psychology, 67, 422-436

Adams, J. S. and Freedman, S. (1976) Equity theory revisited: comments and annotated bibliography in L. Berkowitz and E. Walster (eds) Advances in Experimental Social Psychology, 9, 43-90, New York Academy Press

Agarwal, U. A. (2014) Linking Justice trust and innovative work behaviour to work engagement, Personnel Review, 43(1), 41-73

Altaf, M., Afzal, H., Hamid, K. and Jamil, M. (2011) empirical analysis of organizational justice towards employees' customer oriented behaviour: a case study of medical institutions in Pakistan, African Journal of Business Management, 5(4), 1286-1292

Alvi, A. K. and Abbasi, A. S. (2012) impact of organizational justice on employee engagement in Banking Sector of Pakistan, Middle East Journal of Scientific Research, 12(5), 643-649

Astakhova, M. N. (2015) the curvilinear relationship between work passion and organizational citizenship behaviour, Journal of Business Ethics, 130, 361-374

Astakhova, M. N. and Porter, G. (2015) understanding the work passion-performance relationship: the mediating role of organizational identification and moderating role of fit at work, Human Relations 68(8), 1315-1346

Baard, P. P., E. L. Deci, and R. M. Ryan (2004). Intrinsic Need Satisfaction: A Motivational Basis of Performance 
and Well-Being in Two Work Settings. Journal of Applied Social Psychology 34(10): 2045-2068.

Bies, R. J., \& Moag, J. F. (1986). Interactional justice: Communication criteria of fairness. In R. J. Lewicki, B. H. Sheppard, \& M. H. Bazerman (Eds.), Research on negotiations in organizations (Vol. 1, pp. 43-55). Greenwich, CT: JAI Press.

Bies, R.J. (2001), "Interactional (In)justice: The Sacred and The Profane", in J. Greenberg and R. Cropanzano (eds.), Advances in Organizational Justice, Stanford, CA: Stanford University Press, 89-118

Burke, R. J., Astakhova, M. N. and Hang, H. (2015) work passion through the lens of culture: Harmonious Work Passion, Obsessive Work Passion and work outcomes in Russsia and China, Journal of Business Psychology, $30,457-471$

Byrne, Z. S. and Cropanzano, R. (2001) the history of organizational justice: the founders speak in Cropanzano, R. (2001) Justice in the workplace from theory to practice Lawrence Erlbaum Publishers

Çolak, M. \& Erdost, H. E. (2004). Organizational justice: A review of the literature and some suggestions for future research. Hacettepe University, Journal of Faculty of Economics and Administrative Sciences, 22(2), 51-84.

Colquitt, J. A. 2001. On the dimensionality of organizational justice: A construct validation of a measure. Journal of Applied Psychology, 86: 386-400.

Cropanzano, R., Bowen, D. E. and Gilliland, S. W. (2007) the management of organizational justice, Academy of Management Perspectives, 34-48

Cropanzano, R., Byrne, Z. S., Bobocel, D. M. and Rupp, D. E. (2001) moral virtues, fairness heuristics, social entities and other denizens of organizational justice, Journal of Vocational Behaviour, 58, 164-209

David, J. (2012) how can human resources researchers help employees find, develop and enjoy their work passion and should they? International Employment Relations Review 18(2), 74-89

Deci, E. L., \& Ryan, R. M. (2000). The 'what' and 'why' of goal pursuits: Human needs and the self-determination of behavior. Psychological Inquiry, 11, 227-268.

Deschamps, C., Rinfret, N., and Legace, M. C. (2016) transformational leadership and change: how leaders influence their followers' motivation through organizational Justice, Journal of Healthcare Management, 61(3), 194-213

Egan, R., Turner, M. and Blackman, D. (2017) Leadership and Employee Work Passion: propositions for future empirical investigations, Human Resource Development Review 16(4), 394-424

Emami, M., Esfahan, M. J. and Malmir, M. (2013), an investigation of the relationship between organizational justice and professional organization in Kermanshah, Journal of Management Science Letters, 3, 1333 -1338

Fariba R. D., Sardar M. and Mozafar Y. (2013) Relationship of organizational justice and organizational commitment of the staff in general directorate of youth and sports in Chahar Mahal Va Bakhtiari Province, European Journal of Experimental Biology, 3(5): 376-380

Greenberg, J. (1982) approaching equity and avoiding inequity in groups and organizations, in J. Greenberg and R. L. Cohen (eds) Equity and Justice in Social Behaviour 389-435, New York Academic Press

Greenberg, J. (1987). A taxonomy of organizational justice theories. Academy of Management Review, 12, 9-22.

Greenberg, J. (1990) Organizational Justice: yesterday, today and tomorrow, Journal of Management 16(2), 399432

Gubman, E. (2004) from engagement to passion for work: the search for the missing person, Human Resource Planning, 27(3), $42-46$

Hagel, J., Brown, J. S., Ranjan, A. and Byler, D. (2014) passion at work, cultivating worker passion as a cornerstone of talent development, Deloitte Insights, retrieved June 13, 2018 from www2.deloitte.com

Hassan, A. and Jubari, I. (2010) organizational justice and employee work engagement; LMX as mediator, Journal of International Business and Entrepreneurship Development, 5(2), 167 - 178

Hassan, A. and Jubari, I. H. A. (2010) Organizational justice and employee work engagement: LMX as mediator, Journal of Business and Entrepreneurship Development, 5(2), 167-178

He, H., Zhu, W., and Zheng, X., (2013) Procedural Justice and Employee Engagement: Roles of Organizational Identification and Moral Identity Centrality, Journal of Business Ethics, 122(4), 1-15

Ho, V. T., Wong S., and Lee, C. H. (2011) a tale of passion: Linking job passion and cognitive engagement to employee work performance, Journal of Management Studies, 48(1), 26-47

Ho, V. T., Wong, S. and Lee, C. H. (2011) a tale of passion: linking job passion and cognitive engagement to employee work performance. Journal of Management Studies 48(1), 26-47

Jingjing, L., Zhang, J. and Yang, Z. (2017) association between leaders work passion and an employee's work passion. A moderated mediation model, Frontiers Psychology, 8(1447), 1-12

Kim, J., Nimon, K., Song, J. H. and Zigarmi, D. (2015) Toward Employee work passion and performance: a validation of the work cognitive inventory in Korea, Human Resource Development International, 18(2). $169-190$

Kim, J., Nimon, K., Song, J.H. and Zigarmi, D. (2015) towards employee work passion and performance: a 
validation of the work cognition inventory in Korea, Human Resource Development International 18(2), 169190

Kovacevic, I., Zunic, P. and Mihailovic, D. (2013) concept of organizational justice in the context of academic achievement, Management Journal of Theory and Practice Management, 36-46

Krehniel, P. J. and Cropanzano, R. (2000) Procedural Justice, Outcome favorability and emotion, Social Justice Research 13(4), 339-360

Krejcie, R. V. and Morgan, D. W. (1970) determining sample size for research activities, Educational and Psychological Measurement, 30, $607-610$

Krishnan, R., Loon, K. W., Ahmad, N. A. F. binti, \& Yunus, N. A. S. (2018). Examining the Relationship between Organizational Justice and Job Performance. International Journal of Academic Research in Business and Social Sciences, 8(3), 466-477.

Lather, A. S. and Kaur, S. (2015) Evolution of the concept of organizational justice, Asia Pacific Journal of Research 1(29), 7-25

Ledimo O. and Hlongwane, V. (2014) the role of organizational justice on employee engagement within a public service organization in South Africa, retrieved June 4, 2018 from http://uir.unisa.ac.za/bitstream/handle/10500/21650/role\%20of\%20organisational\%20justice\%20ledimo.pdf ?sequence $=1 \&$ is Allowed $=\mathrm{y}$

Liu, D., Chen, X., Yao, X. (2011) from autonomy to creativity: a multilevel investigation of the mediating role of harmonious passion, Journal of Applied Psychology, 96(2), 294-309

Luo, Z., Bai, X., Min, R., Tang, C. and Fang, P. (2014), Factors influencing the work passion of Chinese community health service workers; an investigation in five provinces, BMC Family Practice 15(17), 1-9

McAllister, C. P., Harris, J. N., Hochwater, W. A., Perrewe, P. L. and Ferris, G. R. (2017) got resources? A multisample constructive replication of perceived resource availability's role in work passion - job outcomes relationships, Journal of Business Psychology, 32, 147-164

McDowall, A., \& Fletcher, C. (2004). Employee development: An organizational justice perspective. Personnel Review, 33(1), 8-29.

Moghimi, S. M., Kazemi, M. and Samiie, S. (2013) studying the relationship between organizational justice and employees' quality of work life in public organizations: a case study of QOM province, Iranian Journal of Management Studies, 6(1), 119-145

Mysalaryscale.com (2017) Employees Salary Analyses in Nigeria for 2017, [News Release] Retrieved October 19, 2018 from https:/www.mysalaryscale.com/blog/employee-salary-analyses-in-nigeria-for2017

Nimon, K. and Zigarmi, D. (2015) the work cognition inventory: initial construct validity for the revised form. Journal of Career Assessment, 23(1), 117-136

Nimon, K., Zigarmi, D., Houson, D., Witt, D. and Diehl, J. (2011) the work cognition inventory: initial evidence of construct validity, Human Resource Development Quarterly, 22(1), 7-35

Okpu Tarela (2016) Employee Voice and Workers Commitment in Nigerian Banking Industry, Lambert Publishers, Germany

Okpu, T. and Kpakol, A.G. (2018) Enhancing Job Engagement through Employee Voice in Nigerian Banking Industry, IOSR Journal of Business and Management, 20 (1), 24-34

Olafsen, A. H., Halvari, H., Forest, J. \& Deci, E. L. (2015). Show them the money? The role of pay, managerial need support, and justice in a self-determination theory model of intrinsic work motivation. Scandinavian Journal of Psychology, 56, 447-457.

Ross, W. D. (1925). The Oxford translation of Aristotle, Vol. IX, The Nichomachean ethics. London: Oxford Press

Shkoler, O., and Tziner, A. (2017) the mediating and moderating role of burnout and emotional intelligence in the relationship between organizational justice and work misbehavior, Journal of Work and Organizational Psychology, 33, 157-164

Shriar, J. (2017) passion for work is more important than engagement, Retrieved June 13, 2018 from www.officeribe.com

Tatum, B. C., \& Eberlin, R. J. (2006). Organizational justice and conflict management styles: Teaching notes, role playing instructions, and scenarios. International Journal of Conflict Management, 17(1), 66-81

Thibault-Landry, A., Egan, R., Crevier-Braud, L.. Manganelli, L. and Forest, J. (2018) an empirical investigation of the employee work passion appraisal model using self-determination theory, Advances in Developing Human Resources, 20(2), 148-168

Thibaut, J. and Walker J. (1975), Procedural Justice: A Psychological Analysis. Hillsdale, NJ: Erlbaum.

Upasna A. A., (2014) "Linking justice, trust and innovative work behaviour to work engagement", Personnel Review, 43(1), 41-73

Vallerand, R. J. (2008). On the psychology of passion: In search of what makes people's lives more worth living. Canadian Psychology, 49, 1-13. 
Zigarmi, D. and Nimon, K. (2011) a cognitive approach to work intention: the stuff that employee work passion is made of, Advances in Developing Human Resources, 13(4), 447-461

Zigarmi, D., Nimon, K., Houson, D., Witt, D. and Diehl, J. (2011) a preliminary field test of an employee work passion model, Human Resource Development Quarterly, 22 (2), 195-221

Zigarmi, D.k, Nimon, K. Houson, D., Witt, D., and Diehl, J., (2009) Beyond engagement: toward a framework and operational definition of employee work passion. Human Development Review, 8(3), 300-326

Zigarmi, E., Houson, D., Witt, D., and Diehl, J. (2011) Employee work passion, connecting the dots, Perspectives, Employee Work Passion retrieved March 17, 2018 from http://engageforsuccess.org/wpcontent/uploads/2015/10/Employee_Passion_Vol.311.pdf 